\title{
Concrete sustainability with very high amount of fly ash and slag
}

\section{Sustentabilidade do concreto com altos teores de escória e cinzas volantes}

G. C. ISAIA

gisaia@terra.com.br

A. L. G. GASTALDINI a gastaldini@terra.com.br

\begin{abstract}
This article approaches concrete mix designs where cement is replaced by high amounts of slag and fly ash, with the purpose of turning it into a more sustainable construction material, that is, an authentic green concrete. Mix proportions with fly ash, ground-blasted furnace slag, and Portland cement were studied in binary and ternary mixtures for compressive strength levels of $40 \mathrm{MPa}$ and $55 \mathrm{MPa}$. The replacement of cement with mineral additions ranged from $50 \%$ to $90 \%$ in mass. Mean decreases of 55\% in the energy consumption, $78 \%$ in the $\mathrm{CO}^{2}$ emissions, and $5 \%$ in the cost of the concrete $\mathrm{m}^{3}$, plus an increase of $40 \%$ in the mean index of durability were obtained, all of which compared to the 40-MPa reference concrete. This study attests the technical, economical and environmental potentialities for the use of concrete mixtures with until $90 \%$ of fly ash.
\end{abstract}

Keywords: sustainability, slag, fly ash, durability, energy consumption, $\mathrm{CO}_{2}$ emission, cost.

\section{Resumo}

Este artigo versa sobre traços de concreto com substituição de cimento por altos teores de escória e cinza volante, com o objetivo de torná-lo um material de construção mais sustentável, ou seja, um autêntico concreto verde. Foram estudados traços de cinza volante, escória de alto forno e de cimento Portland em misturas binárias e ternárias para níveis de resistência à compressão de $40 \mathrm{MPa}$ e 55 MPa. A subsituição de cimento por adições minerais, em massa, variou entre $50 \%$ e $90 \%$. Foram obtidos, em média, decréscimos no consumo de energia de $55 \%$, nas emissões de $\mathrm{CO}^{2}$ de $78 \%$ e no custo do $\mathrm{m}^{3}$ de concreto de $5 \%$, e o índice médio de durabilidade aumentou $40 \%$, todos comparados com o concreto de referência de $40 \mathrm{MPa}$. Este estudo atesta as potencialidades técnicas, econômicas e ambientais do uso de misturas de concreto com até $90 \%$ de cinza volante e escória.

Palavras-chave: sustentabilidade, escória, cinza volante, durabilidade, consumo de energia, emissão de $\mathrm{CO}_{2}$, custo.

\footnotetext{
a Structures and Civil Construction Department Technology Center of the Federal University of Santa Maria (UFSM) - Corresponding author : Rua Camélias, 175, Santa Maria, RS, Brazil, 97020-120, Tel. 555532214417 fax 555532222839 E-mail: gisaia@terra.com.br 


\section{Introduction}

The civil construction consumes great part of the natural resources extracted from the planet and concrete is the greatest cause of this consumption, regarded as the second most consumed material by mankind, topped by water. Klee [1] reports that the cement production in 2002 was $1.56 \mathrm{Gt}$ with an average growth of $4.4 \% / y e a r$ and, Malhotra [2] says that, in the early $21^{\text {st }}$ century, the production of concrete was $12.6 \mathrm{Gt}$. These figures show that the materials used in concrete represent twice as much the world's production for all of the remaining construction materials, which represents the consumption of $2.2 \mathrm{t}$ per inhabitant/year.

Cement consumes $5.5 \mathrm{GJ}$ of energy and liberates, approximately, 1 ton of $\mathrm{CO}$ per ton of clinker corresponding to around $5 \%$ of the total emissions delivered in the atmosphere annually. Considering that each ton of cement requires $1.65 \mathrm{t}$ of raw material or an annual extraction of $2.9 \mathrm{Gt}$ for the cement industry, plus the mining of 12.5 Gt of aggregates for the concrete manufacture, totalizing $15.4 \mathrm{Gt}$, shows the magnitude of the material consumption by the concrete community. On the cement industry's part, these numbers highlight the intense use of natural resources and the gas emission which significantly contributes to global warming.

Mainly since the second half of the $20^{\text {th }}$ century, part of the cement is being replaced by mineral additions, such as fly ash, slag, and other by-products, in order to decrease the environmental impact and increase concrete durability. The know-how and the mastering of both technology and utilization of these residues improved during that period, and they are widely used nowadays in several types of concrete structures. The advantages of this substitution are significant in the technical field, in the economic aspects and, mostly, in the environmental issues because of the reduction in $\mathrm{CO}_{2}$ eq emission, in energy consumption and, many times, in the direct cost, is proportional to the quantity of mineral additions used in the mixture instead of cement. The use of mineral additions such as fly ash and ground granulated blast-furnace slag - in the concrete is worthy because it brings economic advantage when cement, a material of high added value in terms of cost and energy, is replaced by one or more types of mineral additions, by-products which feature economic and energetic low value. This action fits in the sustainability concept where everybody profits: the producer, for delivering a product at a lower cost (or almost always); the consumer, for acquiring a more durable material; and the society, for keeping the environment with lower levels of pollution and better preserving natural resources.

Fly ash and blast-furnace slag are the most used mineral additions due to their great availability and low cost as by-products. The worldwide production of fly ash in the early $21^{\text {st }}$ century was between $480 \mathrm{Mt}$ [2] and $660 \mathrm{Mt}$ [3]. The pig iron production in 2007 was 920 MT [5], which projected an amount of 325 Mt for blastfurnace granulated slag.

The technical and economical advantages that mineral additions have, compared to cement in the concrete structures, are well known, especially durability. Some renowned researchers as P. K. Mehta, R. N. Swamy, V. M. Malhotra, and others published plenty of articles, where they emphatically exposed the advantages of using high amounts of industrial mineral additions instead of Portland cement in concrete production. Mehta [4] declares that superplasticized concrete mixtures containing 60 to $70 \%$ of fly ash or slag in the mass of the total cementitious material have shown high strength and durability at relatively early ages, and that large-scale cement replacement in concrete with these industrial by-products will be highly advantageous from the standpoint of cost economy, energy efficiency, durability and overall ecological profile of concrete.

Based on these guidelines, this work presents an experimental study aiming at quantifying the sustainability advantages of concrete containing from $50 \%$ to $90 \%$ of fly ash and blast-furnace slag, in binary and ternary mixtures. The cost of the materials, the $\mathrm{CO}_{2}$ eq emission, the energy consumption, and the parameters of concrete durability which influence in the rebar corrosion for 40-MPa and 55-MPa compressive strength levels were calculated. The results showed that the replacement of Portland cement with these mineral additions enabled, in one hand, a decrease in cost, as well as in $\mathrm{CO}_{2}$ eq emission, and in the energy consumed and, in the other

\section{Table 1 - Chemical and physical characteristics of the cementitious materials}

\begin{tabular}{|cccc|}
\hline Chemical Analysis \% & Portiland Cement & Fly ash & Blast furnace slag \\
$\mathrm{SiO}_{2}$ & 19.3 & 63.4 & 34.1 \\
$\mathrm{Al}_{2} \mathrm{O}_{3}$ & 4.7 & 26.3 & 12.9 \\
$\mathrm{Fe}_{2} \mathrm{O}_{3}$ & 3.0 & 3.9 & 0.6 \\
$\mathrm{CaO}$ & 63.4 & 1.9 & 41.1 \\
$\mathrm{MgO}$ & 1.8 & 1.0 & 8.2 \\
$\mathrm{SO}_{3}$ & 3.1 & 0.2 & 0.0 \\
$\mathrm{Na}_{2} \mathrm{O}$ & 0.1 & 0.1 & 0.2 \\
$\mathrm{~K}_{2} \mathrm{O}$ & 0.9 & 1.2 & 0.6 \\
Loss of ignition & 3.0 & 1.1 & 0.0 \\
Physical characteristics & & & \\
Specific gravity kg/dm & 3.15 & 2.24 & 2.90 \\
Blaine fineness m $\mathrm{m}^{2} / \mathrm{kg}$ & $\mathrm{n} . \mathrm{a}$. & $\mathrm{n} . \mathrm{a}$. & 470 \\
BET fineness $\mathrm{m}^{2} / \mathrm{kg}$ & 1800 & 350 & $\mathrm{n} . \mathrm{a}$. \\
\hline
\end{tabular}


Table 2 - Mixture proportions per $\mathrm{m}^{3}$ of concrete $\left(\mathrm{kg} / \mathrm{m}^{3}\right)^{*}$

\begin{tabular}{|c|c|c|c|c|c|}
\hline Mixture & $\mathrm{w} / \mathrm{cm}$ & Portiland cement & Fly ash & Slag & Admixture \\
\hline \multirow[t]{3}{*}{ REF } & 0.35 & 540 & & & 0.5 \\
\hline & 0.45 & 393 & & & \\
\hline & 0.55 & 309 & & & \\
\hline \multirow[t]{3}{*}{ 50FA } & 0.35 & 270 & 270 & & 5.1 \\
\hline & 0.45 & 197 & 197 & & 2.4 \\
\hline & 0.55 & 155 & 155 & & 1.6 \\
\hline \multirow{3}{*}{$70 S$} & 0.35 & 162 & & 378 & 2.7 \\
\hline & 0.45 & 118 & & 275 & 1.6 \\
\hline & 0.55 & 93 & & 216 & 1.2 \\
\hline \multirow[t]{3}{*}{ 90SFA } & 0.35 & 54 & 108 & 378 & 2.7 \\
\hline & 0.45 & 39 & 78 & 275 & 0.8 \\
\hline & 0.55 & 31 & 61 & 216 & \\
\hline
\end{tabular}

hand, an increase in durability, highlighting a holistic advantage of replacing cement with high contents of mineral additions.

\section{Experimental study}

This experimental study concerns a research project developed in the Group for Studies and Research in Concrete (GEPECON) of the Post-Graduation Program in Civil Engineering of the Federal University of Santa Maria. The project goal was to study the durability of concrete with high contents of mineral additions, with and without addition of external lime, to observe the replacement of calcium hydroxide reserve depletion, due to the cement decrease in the mixtures and, also, for its consumption by the pozzolanic reactions. In this work are presented only the mixtures without hydrated lime. The following materials were used in the concrete mixtures: type $V$ high-early strength Portland cement, according to Brazilian Standard NBR 5733 (similar to ASTM type III); local natural quartzous sand with maximum characteristic diameter (MCD) of $4.75 \mathrm{~mm}$ and fineness modulus (FM) of 2.2; coarse diabasic aggregate with MCD $=19 \mathrm{~mm}$ and $\mathrm{FM}=6.6$; and policarboxilate ether (PCE) based superplasticizer admixture. The chemical analysis and physical characteristics of the cementitious materials are presented in Table 1. The design proportions were calculated with a cement replacement, in mass, with $50 \%$ of fly ash (FA), $70 \%$ of blast-furnace slag (S), in binary mixtures, and $20 \%$ of fly ash and $70 \%$ of slag (SFA), in ternary mixtures. Due to the different specific gravity between cement and mineral addi-

\section{Table 3 - Results of the compressive strength and the durability tests (91 days)}

\begin{tabular}{|c|c|c|c|c|c|c|}
\hline Mixture & $\mathrm{w} / \mathrm{cm}$ & $\begin{array}{l}91 \text { days } \\
\mathrm{MPa}\end{array}$ & $\begin{array}{l}\text { Carbonation } \\
\text { Coefficient } \\
\text { mm.week }^{-0.5}\end{array}$ & $\begin{array}{l}\text { Chloride } \\
\text { Penetration } \\
\text { coulomb }\end{array}$ & $\begin{array}{l}\text { Retained } \\
\text { Chloride } \\
\text { mmol/kg }\end{array}$ & $\begin{array}{c}\mathrm{Cl} / \mathrm{OH} \\
\text { ratio }\end{array}$ \\
\hline \multirow[t]{3}{*}{ REF } & 0.35 & 72.4 & 0.10 & 2380 & 31.7 & 0.76 \\
\hline & 0.45 & 51.8 & 1.31 & 2800 & 31.6 & 1.00 \\
\hline & 0.55 & 46.1 & 3.53 & 3134 & 33.0 & 1.51 \\
\hline \multirow[t]{3}{*}{ 50FA } & 0.35 & 59.1 & 3.95 & 754 & 21.9 & 0.69 \\
\hline & 0.45 & 30.5 & 7.49 & 925 & 27.4 & 1.44 \\
\hline & 0.55 & 25.4 & 14.61 & 1190 & 28.9 & 2.10 \\
\hline \multirow[t]{3}{*}{705} & 0.35 & 49.1 & 1.02 & 840 & 34.5 & 0.37 \\
\hline & 0.45 & 39.1 & 7.10 & 1030 & 36.5 & 0.71 \\
\hline & 0.55 & 32.6 & 9.08 & 1140 & 44.3 & 0.90 \\
\hline \multirow[t]{3}{*}{ 9OSFA } & 0.35 & 46.1 & 4.64 & 448 & 23.6 & 2.36 \\
\hline & 0.45 & 33.1 & 6.70 & 552 & 29.4 & 1.20 \\
\hline & 0.55 & 20.0 & 14.13 & 651 & 31.0 & 1.32 \\
\hline
\end{tabular}




\section{Figure 1 - Total and unitary cementitious material consumption for $1 \mathrm{~m}^{3}$ of concrete}

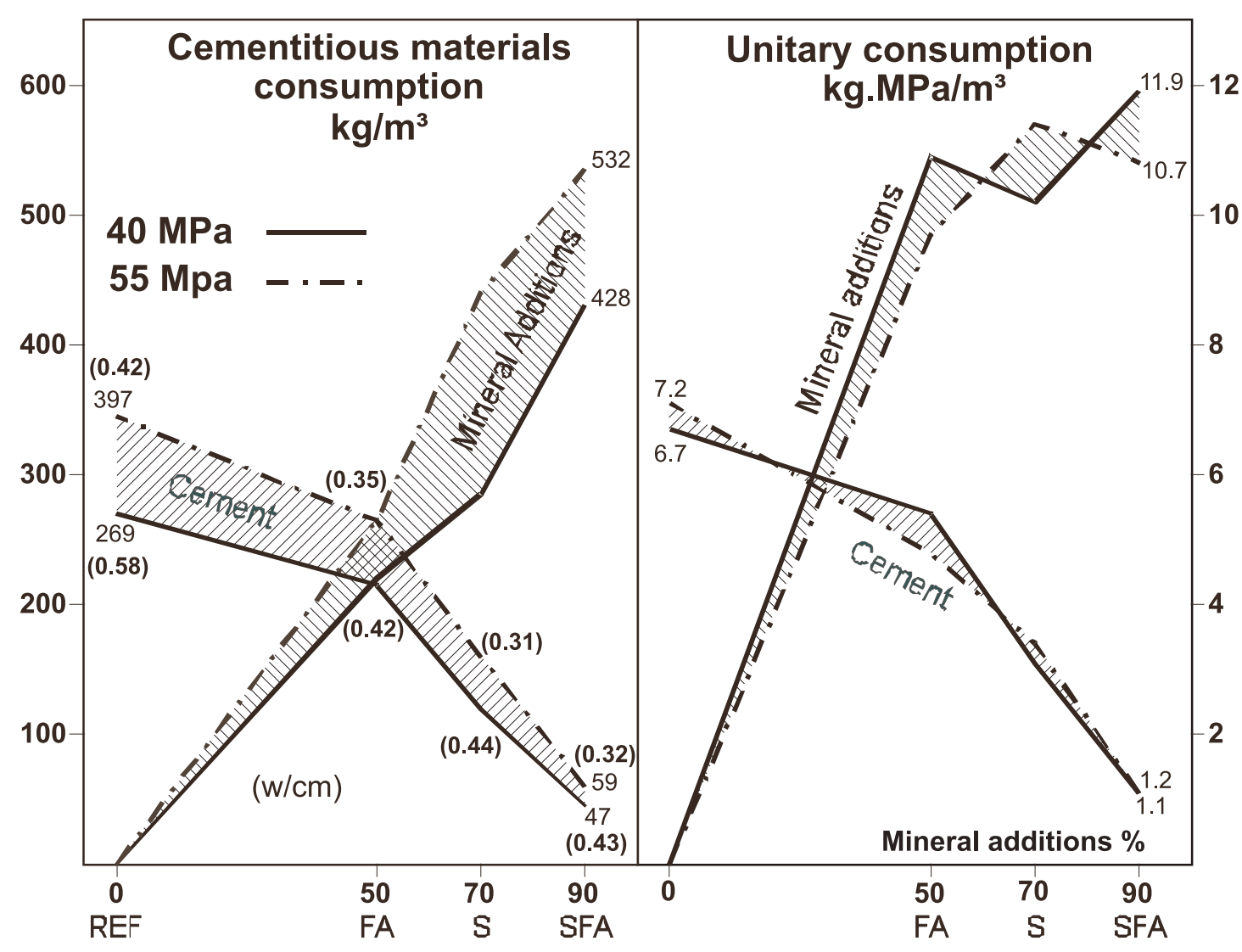

tions, the amount of sand was corrected in order to maintain the same mortar volume of $53 \%$ in concrete. The mixtures were proportioned with $0.35,0.45$ and 0.55 water/cementitious materials $(\mathrm{w} / \mathrm{cm})$ ratio at the same slump range of $60 \pm 15 \mathrm{~mm}$. The quantity of materials per $\mathrm{m}^{3}$ is presented in Table 2. It is relevant to point out that, for the Portland cement consumption, the 90 SFA mixtures contained from $31 \mathrm{~kg} / \mathrm{m}^{3}$ to $54 \mathrm{~kg} / \mathrm{m}^{3}$, only, that is, $10 \%$ of the reference concretes.

For the compressive strength tests, $10 \times 20 \mathrm{~cm}$ specimens were molded according to Brazilian Standard NBR 5738 and tested according to NBR 5739. For the durability study, tests pertinent to rebar corrosion were selected aiming at observing the influence of the high contents of mineral additions in the concrete specimens submitted to those variables that are important to establish the useful life of actual structures. The following durability tests were performed: chloride-ion penetration (ASTM C 1202), total acid-soluble chloride (ASTM C 114 and C1152), $\mathrm{pH}$ potential for calculation of the $\mathrm{Cl} / \mathrm{OH}$, and accelerated carbonation test in climatic chamber with $5 \%$ of $\mathrm{CO}_{2}$, temperature of $23^{\circ} \mathrm{C}$, and $72 \%$ of relative humidity, with carbonation depth measurements at 4, 8 and 12 weeks. The other durability tests were performed at 91 days.

\section{Test results}

Table 3 presents the test results for the axial compressive strength as well as for durability, all of them at 91 days. This age was select- ed in order to highlight the hydration and pozzolanic reactions of fly ash and slag that are slower than the Portland cement only. It must be taken into account that the most important concrete structural members are charged with the total design load in ages higher than 3 months.

Since the specimens' compressive strength ranged between 25.4 and 72.4-MPa at 91 days, two concrete grades for the sustainability study were selected: $40-\mathrm{MPa}$ to represent conventional concrete with $\mathrm{f}_{\mathrm{ck}} \approx 35-\mathrm{MPa}$, and 55-MPa for high-performance concrete with $\mathrm{f}_{\mathrm{ck}} \approx 50-\mathrm{MPa}$. Some data for CAD study were calculated with slight extrapolation $(<10 \%)$, in relation to the test results of the mixtures $70 S$ and 90SFA. For the durability study, the variables were statistically correlated, by non-linear regression, with the respective compression strength data. All statistical regressions presented coefficient of determination $r^{2} \geq 0.85$.

\section{Sustainability study}

\subsection{Data for sustailnability study}

\subsubsection{Cementitious materials}

The amount of cementitious materials per $\mathrm{m}^{3}$ is displayed in Figure 1. While the cement consumption decreased, the amount of min- 


\section{Table 4 - Unitary coefficients of cost, energy and $\mathrm{CO}_{2}$ emissions per ton}

\begin{tabular}{|c|c|c|c|c|}
\hline Materials & $\begin{array}{l}\text { Transport } \\
\text { km }\end{array}$ & $\begin{array}{l}\text { Cost }^{a} \\
\text { US\$. } t^{-1}\end{array}$ & $\begin{array}{l}\text { Energy consumption } \\
\text { MJ. } t^{-1}\end{array}$ & $\begin{array}{c}\mathrm{Co}_{2} \text { emission } \\
\mathrm{kg} \cdot \mathrm{f}^{-1}\end{array}$ \\
\hline Cement & 200 & 120.00 & $5780^{b}$ & $1090^{c}+584^{d}$ \\
\hline Fine aggregate & 60 & 13.00 & 90 & 3 \\
\hline Coarse aggregate & 60 & 20.00 & 140 & 4 \\
\hline Fly ash & 200 & 20.00 & 300 & 10 \\
\hline Slag & 200 & 60.00 & 310 & 10 \\
\hline Admixture & 200 & $4,050.00$ & 15.030 & 94 \\
\hline Water & - & 0.75 & 1.130 & 5 \\
\hline \multicolumn{5}{|c|}{$\begin{array}{l}\text { a Regional average costs, CIF, valid for January 2009, at the exchange rate of R\$2.40/US\$ } \\
\text { ' Average energy consumption by wet and dry processes ( } 9 \text { ) } \\
\text { " Average } \mathrm{CO}_{2} \text { emissions of limestone, fuel and electricity (10) } \\
{ }^{2} \text { See calculus in the text below }\end{array}$} \\
\hline
\end{tabular}

eral additions increased at a higher degree, caused by the drop of the $w / \mathrm{cm}$ ratio needed to reach the desired strength level. So, the higher the contents of mineral additions, the lower the $w / \mathrm{cm}$ because, according to Isaia et al. [6], to reach a desired strength level, the paste must contain a minimum amount of C-S-H (chemical effect) and/or closer contact between the grains (physical effect), in order to reach the target strength. As the efficiency of the mineral additions is lower than the Portland cement, a higher amount of cementitious material is needed to counterbalance the cement substitution, in mass. This behavior is shown by the unitary strength analysis because, while the unitary cement consumption decreases, in average, from 7 to $1 \mathrm{~kg} . \mathrm{MPa} / \mathrm{m}^{3}$ ( 6 times drop) when the contents of mineral additions increases, the cementitious material rises until $11 \mathrm{~kg} . \mathrm{MPa} / \mathrm{m}^{3}$, in order to provide a denser pack for the paste matrix and transition zone.

For the reference mixture, Figure 1 shows a cement consumption of $269 \mathrm{~kg} / \mathrm{m}^{3}$ and $397 \mathrm{~kg} / \mathrm{m}^{3}$ for 40 and 55-MPa strength levels, respectively, while for the mixtures with $20 \%$ of fly ash and $70 \%$ of

\section{Figure 2 - Unitary costs $\left(\mathrm{US} \$ / \mathrm{m}^{3}\right)$ for 40 and $55-\mathrm{MPa}$ strength grades}

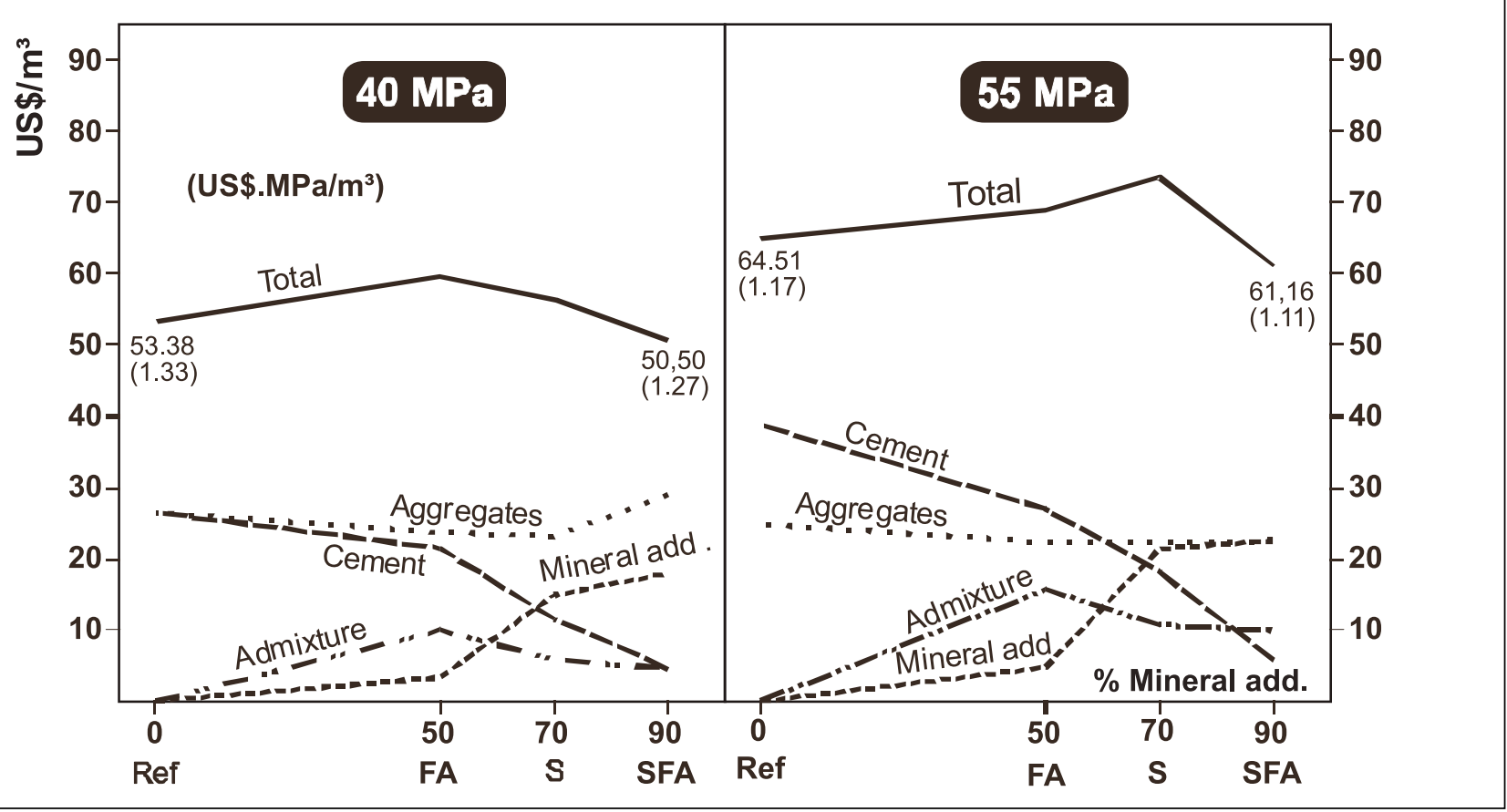




\section{Figure 3 - Total and unitary embedded energy and $\mathrm{CO}_{2 e q}$ emissions per $\mathrm{m}^{3}$ for $\mathbf{4 0}$ and 55-MPa concrete grades}

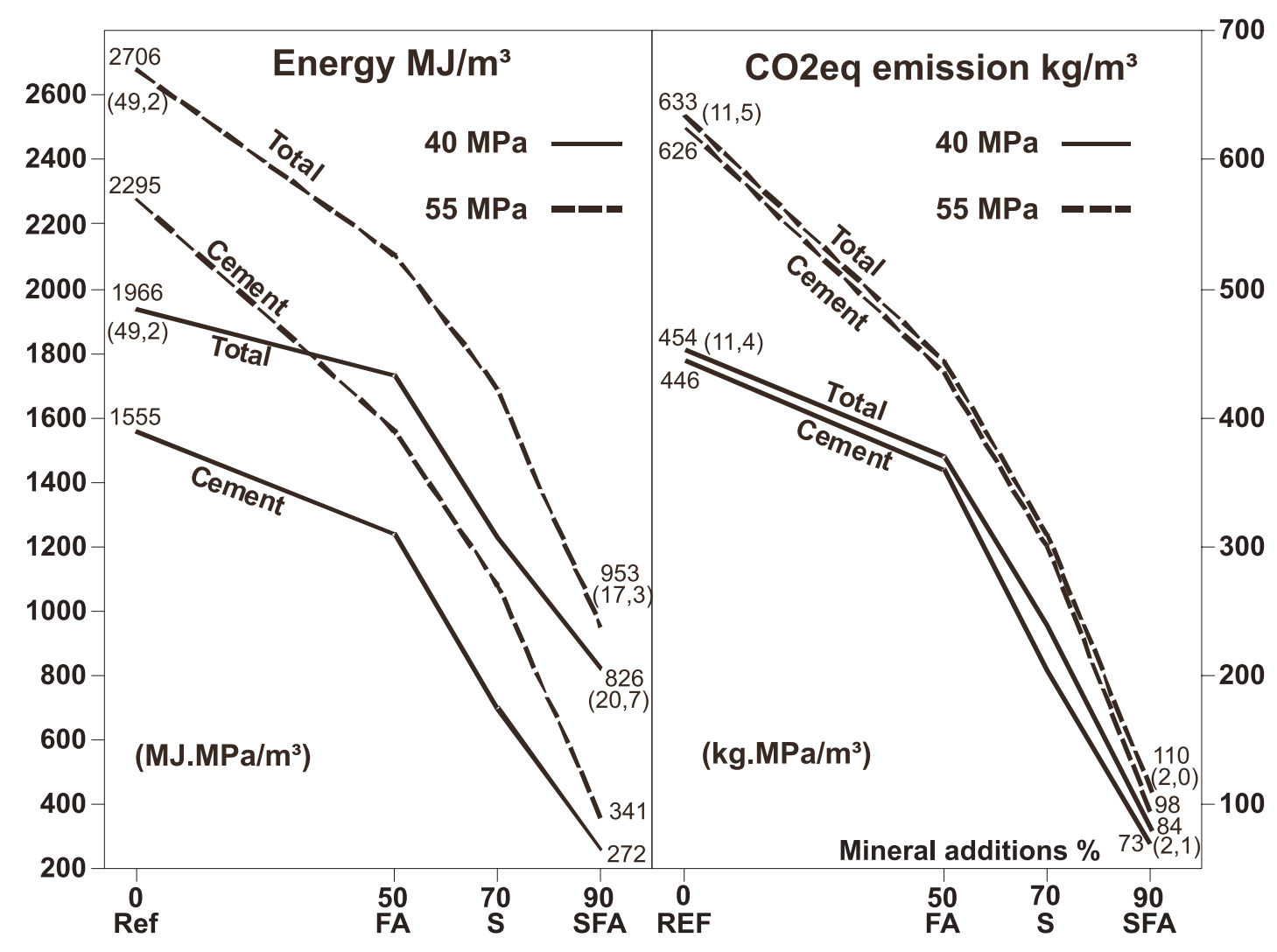

slag (90SFA), these figures decreased to $47 \mathrm{~kg} / \mathrm{m}^{3}$ and $59 \mathrm{~kg} / \mathrm{m}^{3}$, representing an average fall of $84 \%$.

\subsubsection{Unitary cost, energy consumption and $\mathrm{CO}_{2 \mathrm{eq}}$ emission}

Table 4 presents the unitary coefficients of cost, energy and $\mathrm{CO}_{2}$ emissions, per ton. All figures include freight at the appointed transport distance, round trip, to the average cost of US\$ 0,02/t. $\mathrm{km}^{-1}[7]$, with energy consumption of $1.4 \mathrm{MJ} / \mathrm{t} . \mathrm{km}^{-1}[8]$ and $\mathrm{CO}_{2}$ emission of $0.045 \mathrm{~kg} / \mathrm{t} . \mathrm{km}^{-1}$ [9]. The distances were arbitrated for a mediumsized city, simulating a construction located at the outskirts of an urban center.

For the cement manufacture, the $\mathrm{CO}_{2}$ eq average emission for limestone, fuel and electricity was added by part of $\mathrm{NO}_{\mathrm{x}}=1,85$ $\mathrm{kg} \cdot \mathrm{t}^{-1}$ [11], multiplied by a global warm-equivalence potential (GWP) equal to 310 [12] to attainment the $\mathrm{CO}_{2}$ eq's $1.85 .310=584 \mathrm{~kg} \cdot \mathrm{t}^{-1}$. For the sand and coarse aggregate only the extraction energy consumptions were considered, to be the arbitrated $0.1 \mathrm{MJ} / \mathrm{t}^{-1}$ for both aggregates. The energy consumed by the transport and deposition of fly ash and slag was assumed as [8] and the respective $\mathrm{CO}_{2}$ eq

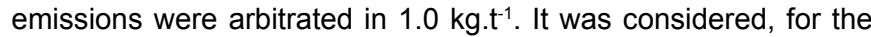
admixture, $30 \%$ of the consumed energy and of the $\mathrm{CO}_{2}$ eq emission for the production of 1 ton of naphtha manufacture, because these admixtures, on average, present $30 \%$ of solids. The energy of water was calculated considering the consumption of a 5-HP pump with $12 \mathrm{~m}^{3} / \mathrm{h}$ flux, and the $\mathrm{CO}_{2}$ eq emission was estimated for water capture, transportation, treatment and storage.

\subsubsection{Concrete cost}

Figure 2 shows that cement presented higher cost for the REF and 50FA mixtures compared to others materials. When the contents of mineral additions increased from 70 to $90 \%$, the aggregates were the materials with preponderant cost, higher than the mineral additions for the 90SFA mixture. The total cost of $\mathrm{REF}_{40}$ was US $\$ 53.38$ and for the 90SFA US $\$ 50.50$, a $5.4 \%$ drop, almost the same for the $\mathrm{REF}_{50}, 5.2 \%$. Obviously, all mixtures for $50-\mathrm{MPa}$ grade showed higher total cost than those for 40-MPa. However, for the unitary cost, per MPa (in brackets), the former were $12 \%$ and $12.5 \%$ lower, respectively, for $\mathrm{REF}_{55}$ and $90 \mathrm{SFA} \mathrm{A}_{55}$ mixtures. The unitary figures show better cost efficiency for the mixtures with higher strength.

\subsubsection{Energy and $\mathrm{CO}_{2 \mathrm{eq}}$ emission}

Figure 3 shows that, for the REF mixture, the cement accumulated from $79 \%$ to $85 \%$ of the total energy, respectively for the 40 and 55 $\mathrm{MPa}$ strength levels. As the amount of mineral additions increased, the energy of the cement decreased, reaching, for 90SFA mixtures, 
Table 5 - Durability test results for 40 and $55-\mathrm{MPa}$

\begin{tabular}{|c|c|c|c|c|c|c|c|c|c|c|c|}
\hline \multirow{2}{*}{$\begin{array}{c}f_{c} \\
M P a\end{array}$} & \multirow{2}{*}{ Mixture } & \multicolumn{2}{|c|}{$\begin{array}{l}\text { Carbonation } \\
\text { Coefficient* }\end{array}$} & \multicolumn{2}{|c|}{$\begin{array}{c}\mathrm{Cl}^{-} \\
\text {penetration }\end{array}$} & \multicolumn{2}{|c|}{$\begin{array}{l}\text { Retained } \\
\text { Chloride }\end{array}$} & \multicolumn{2}{|c|}{$\begin{array}{l}\mathrm{Cl}^{\prime} / \mathrm{OH}^{-} \\
\text {ratio }\end{array}$} & \multicolumn{2}{|c|}{$\begin{array}{l}\text { Mean } \\
\text { index }\end{array}$} \\
\hline & & $\underset{\mathrm{w}^{-0,5}}{\mathrm{~mm}}$ & Ind. & Coul. & Ind. & $\underset{\mathrm{kg}}{\mathrm{mmol} /}$ & Ind. & $\begin{array}{l}\mathrm{Cl}^{-} / \\
\mathrm{OH}^{-}\end{array}$ & Ind. & Total & $\begin{array}{l}\text { Per } \\
\text { MPa }\end{array}$ \\
\hline \multirow{4}{*}{40} & REF & 6.0 & 100 & 3360 & 100 & 32.9 & 100 & 1.6 & 100 & 100 & 100 \\
\hline & 50FA & 6.4 & 107 & 886 & 26 & 24.9 & 76 & 1.1 & 69 & 70 & 70 \\
\hline & $70 S$ & 5.9 & 98 & 990 & 29 & 38.0 & 116 & 0.6 & 38 & 70 & 70 \\
\hline & 90SFA & 5.4 & 90 & 487 & 14 & 25.8 & 78 & 1.3 & 81 & 66 & 66 \\
\hline \multirow{4}{*}{55} & REF & 1.3 & 22 & 2775 & 83 & 32.1 & 98 & 1.1 & 69 & 68 & 50 \\
\hline & 50FA & 3.9 & 65 & 749 & 22 & 22.4 & 68 & 0.7 & 44 & 50 & 36 \\
\hline & $70 S$ & 0.4 & 7 & 779 & 23 & 31.4 & 95 & 0.3 & 19 & 36 & 26 \\
\hline & 90SFA & 4.2 & 70 & 421 & 13 & 23.3 & 71 & 1.0 & 63 & 54 & 39 \\
\hline
\end{tabular}

approximately $1 / 3$ of the total embedded energy. For mineral additions mixtures, the total energy decreased until $58 \%$ for $40-\mathrm{MPa}$ level and $52 \%$ for $50-\mathrm{MPa}$. The unitary energy consumption (in brackets) decreased from 49.2 $\mathrm{MJ} . M P a^{-1}$ for the $\mathrm{REF}_{40}$ to 20.7 and

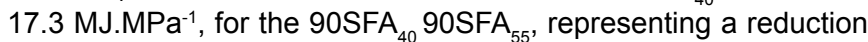
of $58 \%$ and $65 \%$, respectively. These figures demonstrate the ad-

\section{Figure 4 - Performance indexes for cost, energy, $\mathrm{CO}_{2 e q}$ emission and durability pertinent to the 40-MPa compression strength level}

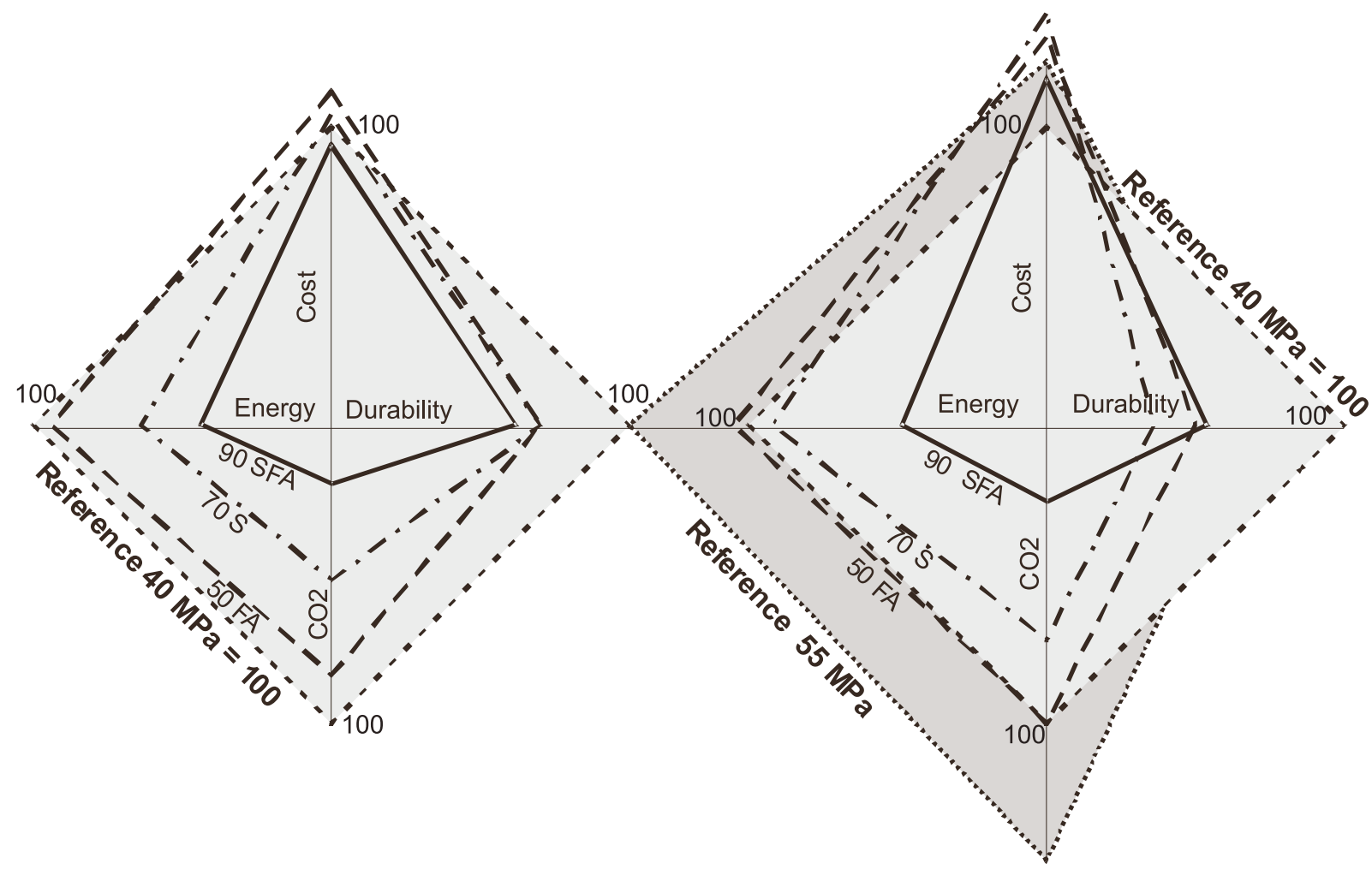


Figure 5 - Unitary indexes for the overall mean performance $\left(\mathrm{I}_{\mathrm{m}} / \mathrm{MPa}\right)$

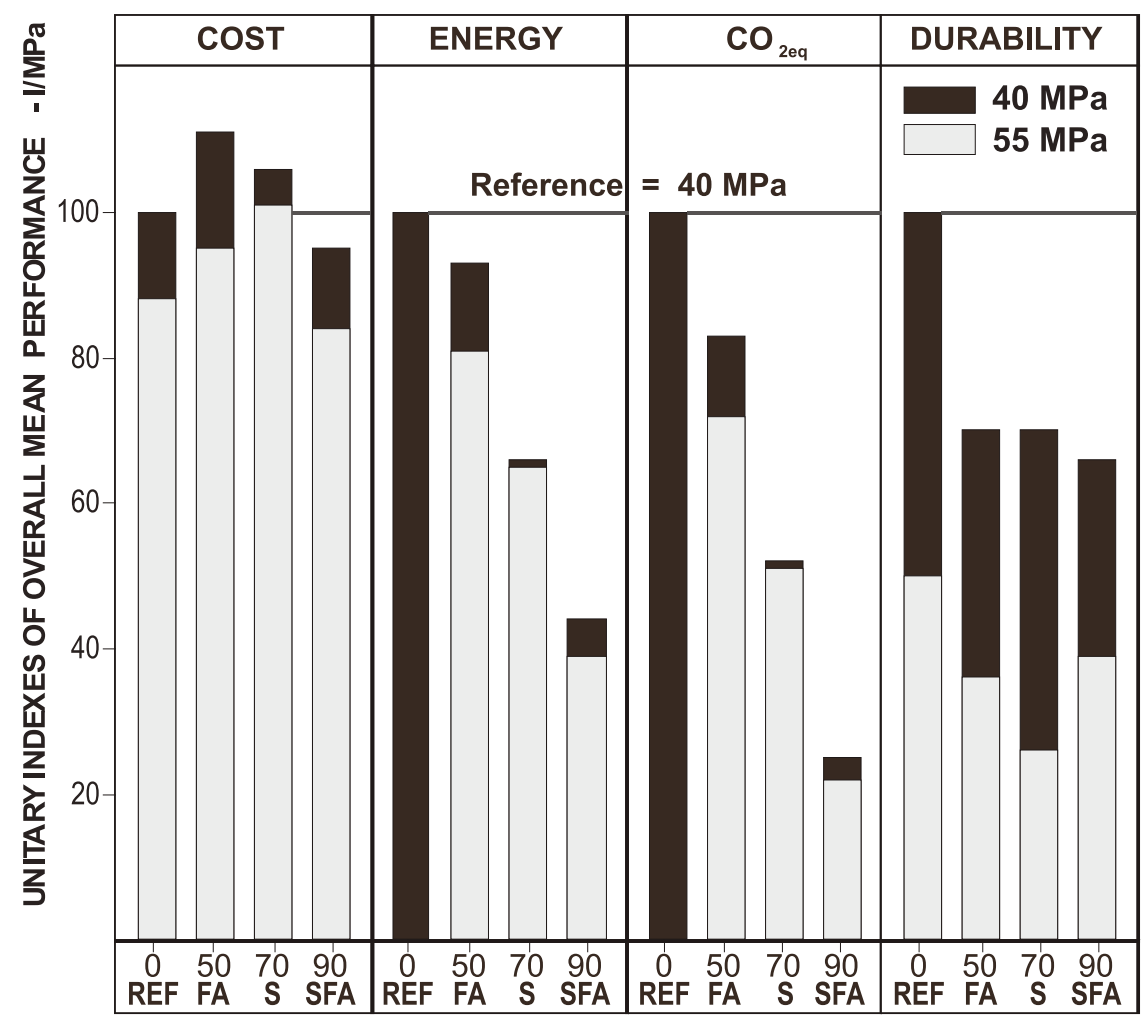

vantage of the smaller specific energetic consumption when the concrete compressive strength is increased.

For the $\mathrm{CO}_{2 \mathrm{eq}}$ emissions, Figure 3 shows a significant environmental gain when cement is replaced with mineral additions, because more than $95 \%$ (except for the 90SFA with $87 \%$ ) of the concrete $\mathrm{CO}_{2 \text { eq }}$ emissions come from Portland cement. For the 90SFA mixtures, the reductions reached $81 \%$ and $76 \%$, respectively, for the 40 and $55-M P A$ levels, respectively, pertinent to the $\mathrm{REF}_{40}$. The unitary emission revealed that the $\mathrm{REF}_{40}$ presented $11.4 \mathrm{~kg} / \mathrm{MPa}$, while all the others with mineral additions had smaller emanation, reaching $1.8 \mathrm{~kg} / \mathrm{MPA}(-84 \%)$ for the 90SFA ${ }_{55}$ mixture. So, the latter emit from 5 to 6 times less $\mathrm{CO}_{2 \mathrm{eq}}$ than the respective reference concrete, per $\mathrm{MPa}$, highlighting again the advantage of using concrete with higher compressive strength.

\subsubsection{Durability}

The results of the durability tests pertinent to the rebar corrosion, for 40-MPa and 55-MPa compressive strength, showed at Table 5, demonstrate the best performance of all variables, making it evident that there is technical viability for cement replacement with mineral additions, up to $90 \%$ in content. These data reveal that 90 SFA $_{55}$ mixture presented a carbonation coefficient of 4.2 mm. week $^{-0.5}$ (42$\mathrm{mm}$ carbonation depth in 100 years), chloride penetration of 421 coulomb (very low, according to ASTM C1202), $23.3 \mathrm{mmol} / \mathrm{kg}$ of total retained chloride, and $1.0 \mathrm{Cl}^{-} / \mathrm{OH}^{-}$ratio, that is, a very durable concrete against corrosion attack.

\subsection{Analysis of the results}

In order to compare all test results together, the 40-MPa strength level data were taken as performance index I = 100; the others were calculated proportionally, even for the 55-MPa grade. For the durability variables the mean indexes of Table 5 are plotted in Figure 4. In general, except for the cost, all indexes related to the energy, $\mathrm{CO}_{2 \mathrm{eq}}$ emission and durability decrease as the contents of mineral additions in the mixtures increased.

Regarding the $\mathrm{REF}_{40}$, the cost of the 90SFA mixture was 5\% lower; for $\mathrm{REF}_{55}$, only the durability performance was benefited by comparison with the same base, because the other indexes are significantly dependent on the contents of cement in the mixture, a material of higher cost, which consumes more energy and emits more $\mathrm{CO}_{2 \mathrm{eq}}$. Figure 5 presents the unitary indexes for the overall mean performance assuming $\mathrm{REF}_{40}=100$. Except for the cost indexes for the 50FA and 70S mixtures, for 40-MPa grade, all others variables presented lower figures compared with the reference, as lower as higher the contents of mineral additions. The 90SFA mixture showed the lowest indexes for the $\mathrm{CO}_{2 \mathrm{eq}}$ emission, with a mean decrease of $81 \%(I=19)$, and for energy, with a mean decrease of $61 \%(I=39)$. The unitary analysis per MPa reveals the advantage of the use of higher strength level, because these mixtures, besides presenting higher cementitious materials consumption and cost, are more efficient and present better cost/benefit ratio compared to the real test data. 
Figure 6 - Overall (OI) and unitary (UI) mean performance indexes for cost, energy, $\mathrm{CO}_{2 \mathrm{eq}}$ emission and durability

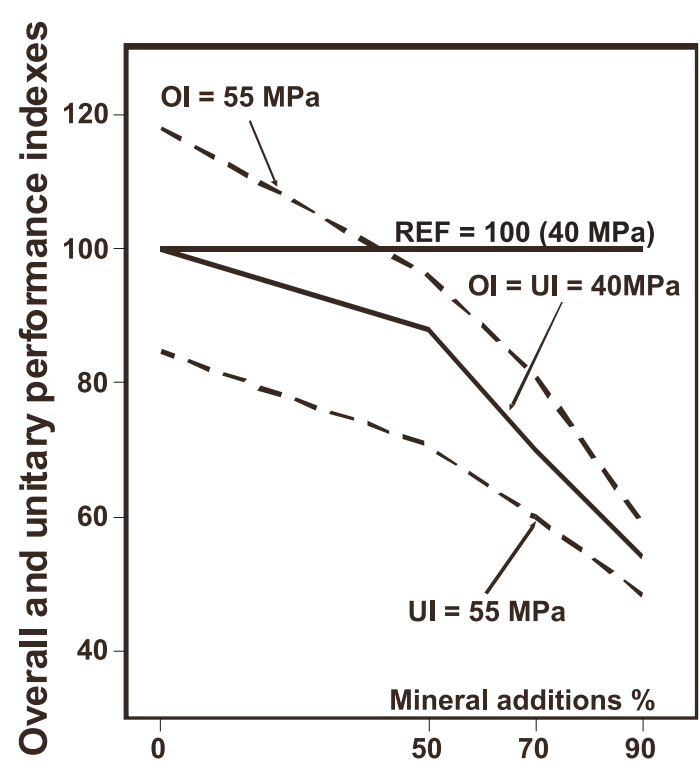

Figure 6 shows the overall performance index (OI), regarding $\mathrm{REF}_{40}=100$. The REF mixture increased to 117 for $55-\mathrm{MPa}$ grade, while, for the unitary index (UI), it decreased to 85 . These indexes show that the increase in strength promoted higher efficiency for the mineral additions mixtures, not only for the durability but, also, for the environmental variables, besides cost. For the unitary indexes, the mixture 90 SFA revealed a decrease of $44 \%$ for $40-\mathrm{MPa}$ and $56 \%$ for $55-\mathrm{MPa}$.

Table 6 presents the differences between the data of a given mixture and the respective reference concrete. It was introduced the variable cement as a comparison term, because it is the most important one, which influences the others from the environmental point of view. The cement consumption decrease was proportional to the contents of mineral additions, reaching $84 \%$, on average, for the mixture 90SFA. For the 50FA and 70S mixtures, the cost presented an increase from 6 to $15 \%$ while, for the 90SFA, a decrease of $5 \%$.

After the cement, the variables that decreased the most, for the 90 SFA mixture, were energy consumption, from $58 \%$ to $65 \%$, and $\mathrm{CO}_{2}$ emission between $81 \%$ and $83 \%$. This last one presented figures close to those of the cement because, practically, all $\mathrm{CO}_{2}$ emitted by the concrete is due to this binder.

Under a durability focus, the differences between the mixtures with mineral additions and the reference mixtures ranged from 30 to $34 \%$ for $40-\mathrm{MPa}$ and 26 to $38 \%$ for the $55-\mathrm{MPa}$. These data are quite different from the cement figures in terms of percentage, because the mechanisms that govern the corrosion process depend on other parameters of the cementitious material (pore and grain size refinement or ionic pores solution), rather than cement (clinker) only.

These figures demonstrate that sustainability of the concrete structures relates directly to the replacement of cement with mineral additions and to the compressive strength level. The less cement is contained in concrete, the higher the characteristics of strength, and the lower the energy consumption and $\mathrm{CO}_{2}$ emission.

\section{Conclusions}

Concrete, the most consumed construction material worldwide, is the ideal repository to shelter industrial residues as blast-furnace slag and fly ash, cementitious materials that possess technical, economical, and social advantages. In this experimental study, the results highlighted that the use of until $90 \%$ of mineral additions to replace the cement mass, the durability average indexes, for the four studied variables connected with the rebar corrosion, decreased $34 \%$ to $40-\mathrm{MPa}$ compressive strength and $46 \%$ to $55-$ $\mathrm{MPa}$, taking $\mathrm{I}_{40 \mathrm{MPa}}=100$. The cost decreased $5 \%$ for the $90 \mathrm{SFA}$ mixture for $40-\mathrm{MPa}$ and equal value regarding $\mathrm{REF}_{55}$.

The energy consumption decreased heavily with the content increase of mineral additions because the cement, alone, contains more than $80 \%$ of the total embedded concrete's energy. For the mixture with $90 \%$ of mineral additions, there was an energy decrease of $58 \%$ for $40-\mathrm{Mpa}$, and of $52 \%$ for $55-\mathrm{MPa}$. The reductions of $\mathrm{CO}_{2}$ emission were, respectively, $81 \%$ and $76 \%$ the highest reduction among all the observed variables.

\begin{tabular}{|c|c|c|c|c|c|c|c|c|c|c|c|}
\hline \multirow{3}{*}{$\begin{array}{c}\mathrm{f}_{\mathrm{c}} \\
\mathrm{MPa}\end{array}$} & \multicolumn{11}{|c|}{$\begin{array}{l}\text { Table } 6 \text { - Differences between mineral additions mixtures and the reference concrete } \\
\qquad\left(\% \text { is associated to the } \operatorname{REF}_{40}\right)\end{array}$} \\
\hline & \multirow[b]{2}{*}{ Mixture } & \multicolumn{2}{|c|}{ P. cement } & \multicolumn{2}{|c|}{ Cost } & \multicolumn{2}{|c|}{ Energy } & \multicolumn{2}{|c|}{$\mathrm{CO}_{2}$} & \multicolumn{2}{|c|}{ Durability } \\
\hline & & $\begin{array}{c}\Delta \\
\mathrm{kg} / \mathrm{m}^{3}\end{array}$ & $\%$ & $\begin{array}{c}\Delta \\
\text { US\$ } / \mathrm{m}^{3}\end{array}$ & $\%$ & $\begin{array}{c}\Delta \\
\mathrm{MJ} / \mathrm{m}^{3}\end{array}$ & $\%$ & $\begin{array}{c}\Delta \\
\mathrm{kg} / \mathrm{m}^{3}\end{array}$ & $\%$ & $\begin{array}{c}\Delta \\
\text { Index }\end{array}$ & $\%$ \\
\hline \multirow{3}{*}{40} & 50FA & 52 & 19 & -6.87 & -11 & 202 & 10 & 84 & 19 & 30 & 30 \\
\hline & $70 s$ & 147 & 55 & -4.04 & -6 & 741 & 38 & 240 & 53 & 30 & 30 \\
\hline & 90ECV & 222 & 83 & 3.48 & 5 & 1140 & 58 & 370 & 81 & 34 & 34 \\
\hline \multirow{3}{*}{55} & 50FA & 130 & 33 & -6.10 & -8 & 614 & 23 & 188 & 30 & 18 & 26 \\
\hline & $70 S$ & 209 & 53 & -11.67 & -15 & 1027 & 38 & 322 & 51 & 21 & 47 \\
\hline & 90ECV & 338 & 85 & 4.04 & 5 & 1753 & 65 & 523 & 83 & 14 & 21 \\
\hline
\end{tabular}


The unitary analysis per MPa for the energy, $\mathrm{CO}_{2 \mathrm{eq}}$ emission and durability prove that the decreases were higher for 55-MPa than for $40-\mathrm{MPa}$, revealing that the advantages increased when the compressive strength was upgraded. Thus, it had been proved that high-strength concretes, besides presenting higher durability by strength unit, also showed best cost/benefit relationships, despite the higher total actual costs.

The results of the present article show that the use of high contents of mineral additions compare technical and economic viability, because there is availability of these residues, throughout the world. Besides, they confer higher durability, significant environmental earnings as well as lower financial costs. The use of large amounts of mineral additions would be an initiative where everybody would gain and, in such manner, they would be contributing, with concrete measures, for the building of environmental sustainability.

The results of the case study show a feasible way to use such huge available amount of slag and fly ash existing all over the world.

\section{Acknowledgements}

The authors thank the CNPq for the financial support and FAPERGS and CNPq for the scholarships, the Companhia Siderurgica Tubarao and BASF for their contributions.

\section{References}

[01] Klee, H. Summary of International Cement Industry Structure and Practice. Draft, 2003. http://www. wbcsd.org/DocRoot/9LEp5LbjBYH9HjCQqbcn/ cement-best-practices.pdf , January, 2009.

[02] Feuerborn, H. J. Coal ash utilization over the world and in Europe. 2005. www.coal-ash.co.il/sadna/ Abstract_Feuerborn.pdf , January, 2009.

[03] Malhotra, V. M. Making concrete 'greener' with fly ash. Concrete International. Farmington Hills, v. 21, n. 5, p. 61-66, 1999.

[04] Mehta, P. K. Bringing the concrete industry into a new era of sustainable development. In: Mario Collepardi Symposium on Advances in Concrete Science and Technology. Proceedings. Rome, 1997, p. 49-68.

[05] Galbraith's Limited. World crude steel and pig iron production. 2008. http://74.125.47.132/ search?q=cache:JGhl1nWwRSUJ:www.galbraiths.Itd. uk/content_manager/document.php\%3Fdbc\%3Ded7d ee7145d2390c49ac4f52c489ac8f\%26ID\%3D7074\% 26ext\%3D.pdf+Galbraith\%E2\%80\%99s+Limi ted+World+crude+steel+and+pig+iron+production\&hl =pt-BR\&ct=clnk\&cd=1\&gl=br, January, 2009.

[06] Isaia, G., Gastaldini, A., Moraes, R. Physical and pozzolanic action of mineral additions on the mechanical strength of high-performance concrete. Cement Concrete and Composites, v. 25, n. 1, p. 69-76, 2003.

[07] NTC - Associação Nacional de Transporte de Cargas. Transport National Guide. 2003. http:// www.ntc.org.br/pesquisa_frota_nacional.htm, January, 2009 (in Portuguese).

[08] Bucher, H. R. E. Aggregates for concrete. In: I National Symposium of Aggregates, São Paulo,
1986. Proceedings. Escola Politécnica da USP, São Paulo 1986 (in portuguese).

[09] Worrell, E., Galitsky, C. Energy efficiency improvement opportunities for cement making. An Energy Star guide for energy and plant managers. 2004. http://www.climatevision.gov/sectors/cement/ pdfs/final_lbnl.pdf, January, 2009.

[10] CEMBUREAU. Cement industry's efforts to reduce $\mathrm{CO}_{2}$ emissions. 2005. http://www.cembureau. be/default.asp?p=Key_09.asp, January, 2009.

[11] Carvalho, J. Environmental lifecycle analysis applied to civil construction - Case study: comparison between Portland cement and by-products addition. 2002. M.Sc. Dissertation. Polytechnic School of São Paulo University, São Paulo.

[12] EPA - Environmental Protection Agency. Greenhouse gases and global warming potential values. 2002, 16 p. http://yosemite.epa.gov/oar/ GlobalWarming.nsf/UniqueKeyLookup/ SHSU5BUM9T/\$File/ghg_gwp.pdf, January 2009. 